ment is dealt with in rotation but on a common plan. The purpose and policy of each is stated and brief allusion is then made to the chief exhibits. The "Illustrated Guide" is completed by an impressive list of publications and the whole is a model of what museum guides should endeavour to be.

\section{Gibberellic Acid-like Substances in Higher Plants}

As earlier studies have shown, gibberellic acid has notable growth-promoting effects when applied to dwarf varieties of Pisum, Phaseolus and maize, whereas tall varieties may be little affected. In an investigation of the distribution of substances similar to gibberellic acid in higher plants, M. Radley has demonstrated the presence of such substances in extracts made from seeds and from all parts of seedlings of tall and dwarf peas and from mature seeds of wheat and french beans (Annals of Botany, N.S., 22, 297 ; 1958). These substances were present in amounts equivalent to $0 \cdot 1-0 \cdot 3 \mu \mathrm{gm}$. gibberellic acid in 100 plants. It is stated that larger quantities were obtained from immature runner bean seeds, the substance being distributed between testas, cotyle. dons and embryos. A new biological test for gibberellic acid-like materials is described.

\section{University News :}

Leeds

THE following gifts have been received among others by the University of Leeds: $£ 1,500$ to the Department of Inorganic and Structural Chemistry from the Royal Society for scientific investigations on high-resolution nuclear magnetic resonance spectroscopy ; $£ 700$ to the Department of Botany from the Royal Society to purchase special equipment; $£ 1,000$ to the Department of Civil Engineering from the Cement and Conerete Association towards the postgraduate course in concrete technology ; $£ 2,715$ to the Houldsworth School of Applied Science over three years from the Department of Scientific and Industrial Research for research on the brittle fracture of metals; and $£ 500$ from the Shell Group of Oil Companies for postgraduate research in chemical engineering; $£ 700$ a year for three years to the Department of Biochemistry from the Wellcome Trust for the salary and expenses of a research assistant.

The following have been appointed lecturers: Dr. P. B. Ayscough in the Department of Physical Chemistry; Dr. R. G. Burwell in anatomy; Dr. A. J. Kenny in biochemistry. The title of reader in textile physics be conferred upon Mr. H. J. Woods, senior lecturer in textile physics.

\section{London}

Mr. F. H. Lud Lam, lecturer in the Department of Meteorology at Imperial College of Science and Technology, has been appointed to the readership in meteorology at the same College. The title of reader in aerodynamics in the University of London has been conferred on Mr. L. E. Fraenkel in respect of his post at the Imperial College of Science and Technology. The title of reader in biology in the University of London has been conferred on Dr. H. Kalmus in respect of his post at University College.

Sheffield

THE title of emeritus professor of zoology has been conferred on Prof. L. E. S. Eastham, who retired recently (see Nature, 181, 1307 ; 1958). The following appointments have also been made: Mr. P. R. Becker, to be lecturer in the Electronic Computation. Laboratory; Dr. P. E. Brown, to be lecturer in geology.

\section{Announcements}

Mr. J. TAnkard (British Rayon Research Association, Wythenshawe, Manchester) and Dr. F. O. Howitt (Wool Industries Research Association, Leeds) have been awarded Service Medals of the Textile Institute. The Service Medal was first awarded in 1940 and is given for valuable services rendered to the Textile Institute.

Starting with the January 1959 issue, Consultants Bureau, Inc., is undertaking the translation of all non-English articles appearing in each issue of the Czechoslovak Journal of Physics (annual subscription : 6 issues, 50.00 dollars). Further information can be obtained from Consultants Bureau, Inc., 227 West 17th Street, New York 11.

A symposium on "The Chemistry of Co-ordination Compounds", organized by the National Academy of Sciences, India, will be held in Allahabad on February 7 and 8. Further information can be obtained from Dr. Arun K. Dey, Department of Chemistry, University of Allahabad, India.

IT is proposed to hold a symposium on "Cultural and Metabolic Aspects of Moulds", organized jointly by the Society for Applied Bacteriology and the Istituto di Sanita in Rome in the spring of 1960. The symposium will be open to bona fide workers in this field whether they are members of the Society or not. Those interested should write to Mr. G. Sykes, Boots Pure Drug Co., Ltd., Microbiology Division, Standard Department, West Bridgford, Nottingham, as soon as possible.

AN international symposium on antibiotics will be held in Prague during May 17-23. The proceedings will be divided into three sections, dealing with problems of the biosynthesis of antibiotics; the scientific pathophysiological basis of antibiotic therapy; and the problems of fermentation technology and non-medical use of antibiotics. Further information can be obtained from the secretary of the symposium, Dr. M. Hermanský, Antibiotics Research Institute, Roztoky, near Prague, Czechoslovakia.

A JoINT endocrine meeting will be held at the Royal Society of Medicine on April 24 and 25, 1959. It will be sponsored by the Section of Endocrinology of the Royal Society of Medicine and the Society for Endocrinology with the participation of the Society for the Study of Fertility, the Medical Section of the British Diabetic Association, the London Thyroid Club and the Endocrine Club, Glasgow. Short papers will be read and a dinner will be held on April 24 . Further details can be obtained from the Honorary Secretary, Section of Endocrinology, Royal Society of Medicine, 1 Wimpole Street, London, W.1.

Erratum. In the communication entitled "Solubilization' of a Cytochrome $b$ Component from Micrococcus lysodeikticus", by F. L. Jackson and Valerie D. Lawton in Nature, 182, 799 (1958), para. 3, line 7 , for " $529-530 \mathrm{~m} \mu$ " read " $429-430 \mathrm{~m} \mu$ ". This was overlooked in proof by the authors. 